Check for updates

Portsmouth

Cite this as: $B M J$ 2021;373:n879 http://dx.doi.org/10.1136/bmj.n879 Published: 01 April 2021

\title{
Covid-19: Brazil's spiralling crisis is increasingly affecting young people
}

\section{Luke Taylor}

Brazil continues to break records for all the wrong reasons as it faces its deadliest episode of the pandemic yet, amid an escalating political crisis.

More than 3780 covid-19 deaths were recorded on 30 March, six days after the country recorded its 300 oooth life lost to the illness. At least 60 ooo Brazilians died with covid-19 in March as the more transmissible variant known as P.1 spread across the country.

A flurry of high profile resignations ${ }^{1}$-including the foreign and defence ministers and the heads of the army, navy, and air force-have added to the woes of President Jair Bolsonaro. Critics hold Bolsonaro responsible for the country's sobering covid-19 death tally, as he has played down the threat of the virus and refused to implement stricter measures to slow its spread.

Now, experts have warned that covid-19 is now affecting young Brazilians worse than ever before. Doctors treating covid-19 patients have reported that more young people are being admitted to their hospitals in the current wave of cases. ${ }^{2}$ Their observations are being corroborated by a series of new studies looking at infection and mortality rates in Brazil.

Covid-19 cases among people in their 30s, 40s, and 50 are up by 565\%, 626\%, and 525\% respectively since the beginning of January, says the Oswaldo Cruz Foundation (Fiocruz), ${ }^{3}$ a research institute attached to Brazil's Ministry of Health. The comparatively lower increase in the overall population "suggests a shift to younger age groups," it concluded in a bulletin published on 26 March.

Raphael Guimarães, an epidemiologist at Fiocruz, has said that cases in the younger population have likely increased because they are less able to practice social distancing and thus run a higher risk of getting infected when the virus is prevalent.

"The younger population, either due to the exhaustion of being confined, or due to the need for face-to-face work, has been more crowded than the older population," he said.

\section{More transmissible}

Covid-19 cases have soared throughout Brazil in the past month and have been attributed to the spread of P.1, which is estimated to be 1.4-2.2 times more transmissible than previous variants. ${ }^{4}$

Growing evidence shows that young people are not only more likely to get infected with P.1 but also to die from it, some experts have warned. The Brazilian Association of Intensive Care Medicine said that the number of 18-45 year olds requiring intensive care for covid-19 in February to March this year was three times greater than in September to November 2020, ${ }^{5}$ and coronavirus related deaths in that age group have almost doubled.

Maragareth Portela, a senior researcher at Fiocruz, said that Brazil's saturated hospitals could partly explain the higher mortality rates, as patients were less likely to survive if beds and equipment were short and staff were overwhelmed.

Yet the increase is higher in regions where P.1 is more prevalent, suggesting that it is not only more transmissible but also more lethal. "It is very likely that the P.1 variant is more severe among young adults," said Portela.

The case of Manaus, the capital of Brazil's Amazonas region where the P.1 variant first emerged in November 2020-causing hospitals to collapse and moralities to soar-also points to P.1 being more lethal.

A preliminary study, ${ }^{6}$ which compared case fatality rates in Manaus's first wave of cases in April to May 2020 with the second wave in January 2021, found that deaths among people aged 20-39 were 2.7 times higher in the second wave than in the first. In the general population they were only 1.15 times higher.

"If overload was the reason for the increase in the case fatality rate, it would be reasonable to expect that the increase would be similar for different ages and genders," said André Ricardo, epidemiologist at the Leopoldo Mandic School of Medicine in São Paulo and one of the study's authors. "P.1 appears to be more lethal among young men and women than the original strain.”

Brazil: Political crisis and Covid surge rock Bolsonaro. BBC News 2021 Mar 31. https://www.bbc.co.uk/news/world-latin-america-56581131.

2 Rivers M. Why are more young people getting sick with Covid-19 in Brazil? CNN2021 Mar 25. https://edition.cnn.com/2021/03/24/americas/brazilyouth-covid-19-intl-latam/index.html.

3 Castro R. Observatório Covid-19 Fiocruz alerta para rejuvenescimento da pandemia no Brasil [Covid-19 Fiocruz Observatory warns of pandemic rejuvenation in Brazil]. Fiocruz News Agency 2021 Mar 26. https://agencia.fiocruz.br/observatorio-covid-19-fiocruz-alerta-para-rejuvenescimentoda-pandemia-no-brasil. [In Portuguese.]

4 Faria NR, Mellan TA, Whittaker C, et al. Genomics and epidemiology of a novel SARS-CoV-2 lineage in Manaus, Brazil. 2021. https://github.com/CADDE-CENTRE/Novel-SARS-CoV-2-P1-Lineage-inBrazi//blob/main/manuscript/FINAL_P1_MANUSCRIPT_25-02-2021_combined.pdf.

5 Peet C. "A miracle I survived”: Younger Brazilians hit by COVID surge. Al Jazeera 2021 Mar 21. https://www.aljazeera.com/news/2021/3/28/miracle i-survived-younger-brazilians-hit-covid-surge.

6 Freitas ARR, Beckedorff OA, Cavalcanti LP, et al. The emergence of novel SARS-CoV-2 variant P.1 in Amazonas (Brazil) was temporally associated with a change in the age and gender profile of COVID-19 mortality. Sci ELO 2021 [preprint]. https://preprints.scielo.org/index.php/scielo/preprint/view/2030

This article is made freely available for use in accordance with BMJ's website terms and conditions for the duration of the covid-19 pandemic or until otherwise determined by BMJ. You may use, download and print the article for any lawful, non-commercial purpose (including text and data mining) provided that all copyright notices and trade marks are retained. 